\title{
ANALISIS KINERJA KEUANGAN PERUSAHAAN YANG TERDAFTAR DI BEI BERBASIS RASIO LIKUIDITAS, PROFITABILITAS, SOLVABILITAS DAN AKTIVITAS (Studi Komparasi pada PT Indofood CBP Sukses Makmur Tbk dan PT Nippon Indosari Corpindo Tbk)
}

\author{
Moh. Zaki Kurniawan \\ Dosen Fakultas Ekonomi Universitas Islam Balitar Blitar \\ e-mail: zaki.kurniawan3@gmail.com
}

\begin{abstract}
ABSTRAK
Laporan keuangan bertujuan untuk mengetahui kinerja keuangan perusahaan PT Indofood CBP Sukses Makmur Tbk dan PT Nippon Indosari Corpindo Tbk yang berdasarkan rasio likuiditas, profitabilitas, solvabilitas, dan aktivitas. Subyek penelitian ini adalah PT Indofood CBP Sukses Makmur Tbk dan PT Nippon Indosari Corpindo Tbk. Obyek dalam penelitian ini meliputi rasio likuiditas, rasio profitabilitas, solvabilitas, aktivitas dan kinerja keuangan. Data dikumpulkan dengan metode dokumentasi. Data dianalisis menggunakan perhitungan rasio likuiditas, rasio solvabilitas, rasio profitabilitas dan rasio aktivitas. Hasil penelitian menunjukan bahwa : (1) rasio likuiditas PT Indofood CBP Sukses Makmur Tbk lebih baik dari PT Nippon Indosari Corpindo Tbk, (2) rasio profitabilitas PT Nippon Indosari Corpindo Tbk lebih baik dari PT Indofood CBP Sukses Makmur Tbk, (3) rasio solvabilitas PT Indofood CBP Sukses Makmur Tbk lebih baik dari PT Nippon Indosari Corpindo Tbk, (4) rasio aktivitas PT Indofood CBP Sukses Makmur Tbk lebih baik dari PT Nippon Indosari Corpindo Tbk.
\end{abstract}

Kata kunci : rasio likuiditas, rasio profitabilitas, rasio solvabilitas, rasio aktivitas, kinerja keuangan.

\section{LATAR BELAKANG}

Jumingan (Gandi, 2015) menyatakan bahwa kinerja keuangan merupakan gambaran kondisi keuangan perusahaan pada suatu periode tertentu baik menyangkut aspek penghimpunan dana maupun penyaluran dana, yang biasanya diukur dengan indikator kecukupan modal, likuiditas, dan profitabilitas. Salah satu cara untuk menganalisis kinerja keuangan pada saat ini maupun pada saat mendatang adalah dengan cara menganalisis laporan perusahaan yang terdiri dari neraca dan laporan laba rugi. Alat analisis yang sering digunakan untuk mengetahui kinerja keuangan adalah rasio keuangan. Analisis laporan keuangan sebagai pengurai pos-pos laporan keuangan menjadi unit informasi yang lebih kecil dan melihat hubungannya yang bersifat signifikan atau mempunyai makna antara satu dengan yang lain baik data kuantitatif maupun non kuantitatif dengan tujuan untuk mengetahui kondisi keuangan lebih dalam yang sangat penting dalam proses menghasilkan keputusan yang tepat. Analisis rasio keuangan bersifat menyeluruh karena mencangkup efisiensi perusahaan dalam pengunaan aktivanya dan dapat mengukur tingkat keuntungan yang dihasilkan perusahaan. 


\section{TINJAUAN PUSTAKA}

\section{LAPORAN KEUANGAN}

Laporan keuangan pada hakikatnya bersifat umum dan sangat penting untuk memperoleh informasi dengan adanya pihak-pihak tertentu yang berkepentingan terhadapa laporan keuangan tersebut. Laporan keuangan akan lebih berarti jika pihak-pihak yang berkepentingan memperoleh informasi keuangan yang dapat mendukung kebijakan yang akan di ambil, karena laporan keuangan merupakan hasil akhir dari proses pencatatan yang merupakan ringkasan-ringkasan dari transaksi-transaksi keuangan yang terjadi selama tahun buku yang bersangkutan. Laporan keuangan adalah laporan pertanggungjawaban manajer atau pimpinan perusahaan atas pengelolaan perusahaan yang dipercayakan kepadanya kepada pohak-pihak yang berkepentingan (stakeholder) terhadap perusahaan; yaitu pemilik perusahaan (pemegang saham), pemerintah (instansi pajak), kreditur (bank atau lembaga keuangan), maupun pihak yang berkepentingan lainnya (Rahardjo, 2007:53), .

\section{ANALISIS RASIO KEUANGAN}

Rasio keuangan dalah suatu kajian yang melihat perbandingan antara jumlah-jumlah yang terdapat pada laporan keuangan dengan mempergunakan formula-formula yang dianggap representatif untuk diterapkan (Fahmi, 2012:49). Rasio keuangan atau financial ratio ini sangat penting untuk melakukan nalisa terhadap kondisi keuangan perusahaan. Bagi investor jangka pendek dan mengah pada umumnya lebih banyak tertarik kepada kondisi keuangan jangka pendek dan kemampuan perusahaan untuk membayar deviden yang memadai. Informasi tersebut dapat diketahui dengan cara yang lebih sederhana yaitu dengan menghitung rasio-rasio keuangan yang sesuai dengan keinginannya. Secara jangka panajng rasio keuangan dapat dijadikan sebagai acuan dalam menganalisis kondisi kinerja suatu perusahaan, misalnya kondisi kinerja perusahaan selama 10 s.d 12 tahun ke depan. Namun analisa seperti itu jarang dilakukan, karena belum tentu kondisi stabilitas penilaian suatu kondisi keuangan perusahaan dipengaruhi oleh faktor-faktor yang menyebabkan perubahan pada kondisi keuangan seperti kondisi ekonomi mikro maupun ekonomi makro bain yang terjadi di tingkat domestik ataupun internasional.

\section{KINERJA KEUANGAN}

Kinerja keuangan perusahaan merupakan prestasi yang dicapai perusahaan dalam suatu periode tertentu yang mencerminkan tingkat kesehatan perusahaan tersebut (Sutrisno, 2009:53). Kinerja keuangan adalah suatu analisis yang dilakukan untuk melihat sejauh mana suatu perusahaan telah melaksanakan dengan menggunakan aturan-aturan pelaksanaan keuangan secara baik dan benar. Kinerja perusahaan merupakan suatu gambaran tentang kondisi keuangan suatu perusahaan yang dianalisis dengan alat-alat analisis keuangan, sehingga dapat diketahui mengenai baik buruknya keadaan keuangan suatu perusahaan yang mencerminkan prestasi kerja dalam periode tertentu. Hal ini sangat penting agar sumber daya digunakan secara optimal dalam menghadapi perubahan lingkungan (Fahmi, 2011:2).

Dari beberapa pengertian di atas, dapat disimpulkan bahwa kinerja keuangan adalah gambaran kondisi keuangan perusahaan pada satu periode yang 
menyangkut aspek penghimpunan dana maupun penyaluran dana yang dapat dianalisis dengan alat-alat analisa rasio keuangan untuk mengukur keadaan perusahaan tersebut baik atau tidak.

Adapun penilaian kinerja menurut Srimindarti (2006:34) adalah penentuan efektivitas operasional, organisasi, dan karyawan berdasarkan sasaran, standar dan kriteria yang telah ditetapkan sebelumnya secara periodik. Pengukuran kinerja digunakan perusahaan untuk melakukan perbaikan di atas kegiatan operasionalnya agar dapat bersaing dengan perusahaan lain. Analisis kinerja keuangan merupakan proses pengkajian secara kritis terhadap review data, menghitung, mengukur, menginterprestasi, dan memberi solusi terhadap keuangan perusahaan pada suatu periode tertentu.Menurut Munawir (2012:31) menyatakan bahwa tujuan dari pengukuran kinerja keuangan perusahaan adalah:

1. Mengetahui tingkat likuiditas.

2. Mengetahui tingkat solvabilitas.

3. Mengetahui tingkat rentabilitas.

4. Mengetahui tingkat stabilitas.

\section{RASIO LIKUIDITAS}

Ketidakmampuan perusahaan membayar kewajibannya terutama utang jangka pendek / yang sudah jatuh tempo disebabkan oleh beberapa faktor. Pertama, bisa dikarenakan perusahaan sedang tidak memiliki dana atau kedua, bisa mungkin saja perusahaan memiliki dana, saat jatuh tempo perusahaan tidak memiliki dana (tidak cukup) secara tunai sehingga harus menunggu dalam waktu tertentu, untuk mencairkan aktiva lainnya seperti menagih piutang, menjual suratsurat berharga atau menjual sediaan atau aktiva lainnya. Penyebab utama kejadian kekurangan dan ketidakmampuan perusahaan untuk membayar kewajibannya tersebut adalah akibat kelalaian manajemen perusahaan dalam menjalankan usahanya. Sebab lainnya adalah sebelumnya pihak manajemen perusahaan tidak menghitung rasio keuangan yang diberikan sehingga tidak mengetahui bahwa sebenarnya kondisi perusahaan sudah dalam keadaan tidak mampu lagi karena nilai utangnya lebih tinggi dari harta lancarnya. Menurut Weston dan Copeland (1995:254), rasio likuiditas adalah rasio untuk mengukur kemampuan perusahaan untuk memenuhi kewajiban keuangan jangka pendek.

Current Ratio / Rasio Lancar adalah rasio untuk mengetahui kesanggupan memenuhi kewajiban jangka pendek dengan seberapa jauh tuntutan dari kreditur jangka pendek. Current Ratio dapat dihitung dengan rumus :

Current Ratio $=\frac{\text { Aktiva Lancar }}{\text { Kewajiban Lancar }}$

Ada penilaian Current Ratio berdasarkan Peraturan Menteri Negara Koperasi dan Usaha Kecil dan Menengah Republik Indonesia, Nomor 06/Per/M.KUKM/V/2006 tanggal 1 Mei 2006 tentang Pedoman Penilaian Koperasi Berprestasi/Koperasi Award dalam Pratama (2016:33) sebagai berikut :

Tabel 1

Penilaian Current Ratio

\begin{tabular}{|l|c|}
\hline \multicolumn{1}{|c|}{ Kriteria } & Standart \\
\hline Baik Sekali & $200 \%-250 \%$ \\
\hline Baik & $175 \%-<200 \%$ atau $>250 \%-275 \%$ \\
\hline
\end{tabular}




\begin{tabular}{|l|c|}
\hline Cukup Baik & $150 \%-<175 \%$ atau $>275 \%-300 \%$ \\
\hline Kurang Baik & $125 \%-<150 \%$ atau $>300 \%-325 \%$ \\
\hline Tidak Baik & $<25 \%$ atau $>325 \%$ \\
\hline
\end{tabular}

Sumber : Pratama (2016)

\section{RASIO PROFITABILITAS}

Menurut Sartono (2010:122), rasio profitabilitas adalah kemampuan perusahaan memperoleh laba dalam hubungannya dengan penjualan. Return On Invesment (ROI) adalah kemampuan perusahaan untuk menghasilkan laba dari aktiva yang ada. Return On Invesment dapat dihitung dengan rumus :

Return On Invesment $=\frac{\text { Laba setelah Pajak }}{\text { Total Aktiva }}$

Penilaian Rentabilitas Ekonomi berdasarkan Peraturan Menteri Negara Koperasi dan Usaha Kecil dan Menengah Republik Indonesia, Nomor 06/Per/M.KUKM/V/2006 tanggal 1 Mei 2006 tentang Pedoman Penilaian Koperasi Berprestasi/Koperasi Award dalam Pratama (2016:28) sebagai berikut :

Tabel 2

Standart Penilaian ROI

\begin{tabular}{|l|c|}
\hline \multicolumn{1}{|c|}{ Kriteria } & Standart \\
\hline Baik Sekali & $>10 \%$ \\
\hline Baik & $7 \%-<10 \%$ \\
\hline Cukup Baik & $3 \%-<7 \%$ \\
\hline Kurang Baik & $1 \%-<3 \%$ \\
\hline Tidak Baik & $<1 \%$ \\
\hline
\end{tabular}

Sumber : Pratama (2016)

\section{RASIO SOLVABILITAS}

Menurut Weston dan Copeland (1995:253-254) rasio solvabilitas merupakan rasio untuk mengukur kemampuan perusahaan untuk memenuhi kewajibannya jangka panjang yang total hutangnya lebih besar dibandingkan dengan total asetnya. Total Debt to Total Capital Assets adalah rasio untuk mengukur jumlah investasi ekuitas pemegang saham oleh pengguna hutang untuk membiayai total asset. Rasio ini dapat dihitung dengan rumus :

Total Debt to Total Capital Assets $=\frac{\text { Total Hutang }}{\text { Total Aktiva }}$

Penilaian Total Debt to Total Capital Assets berdasarkan Peraturan Menteri Negara Koperasi dan Usaha Kecil dan Menengah Republik Indonesia, Nomor 06/Per/M.KUKM/V/2006 tanggal 1 Mei 2006 tentang Pedoman Penilaian Koperasi Berprestasi/Koperasi Award dalam Pratama (2016:34) sebagai berikut :

Tabel 3

Standart Penilaian Total Debt to Total Capital Asset

\begin{tabular}{|c|c|}
\hline Kriteria & Standar \\
\hline Baik Sekali & $<40 \%$ \\
\hline Baik & $>40 \%-50 \%$ \\
\hline Cukup Baik & $>50 \%-60 \%$ \\
\hline Kurang Baik & $>60 \%-80 \%$ \\
\hline Tidak Baik & $>80 \%$ \\
\hline
\end{tabular}

Sumber : Pratama (2006) 


\section{RASIO AKTIVITAS}

Menurut Arifin (2004:11-12) Rasio Aktivitas adalah rasio untuk mengukur seberapa efektif perusahaan menggunakan sumber daya yang dimiliki. Total Assets Turn Over adalah rasio untuk mengukur kemampuan dana yang tertanam dalam aktiva pada suatu periode (Arifin, 2004:11-12). Rasio ini memperlihatkan efektivitas perusahaan dalam mengelola perputaran komponen aktiva. Total Assets Turn Over dapat dihitung dengan rumus :

Total Assets Turn Over $=\frac{\text { Penjualan Netto }}{\text { Total aktiva }}$

Penilaian Assets Turn Over berdasarkan Peraturan Menteri Negara Koperasi dan Usaha Kecil dan Menengah Republik Indonesia, Nomor 06/Per/M.KUKM/V/2006 tanggal 1 Mei 2006 tentang Pedoman Penilaian Koperasi Berprestasi/Koperasi Award dalam Aprilia (2014:7) sebagai berikut :

\section{Tabel 4}

Standart Penilaian Total Assets Turn Over

\begin{tabular}{|c|c|}
\hline Kriteria & Standar \\
\hline Sehat & $>3,5 \mathrm{kali}$ \\
\hline Cukup Sehat & $2,5 \mathrm{kali} / \mathrm{d}<3,5 \mathrm{kali}$ \\
\hline Kurang Sehat & $1,5 \mathrm{kali} \mathrm{s} / \mathrm{d}<2,5 \mathrm{kali}$ \\
\hline Tidak Sehat & $1 \mathrm{kali} \mathrm{s} / \mathrm{d}<1,5 \mathrm{kali}$ \\
\hline Sangat Tidak Sehat & $<1 \mathrm{kali}$ \\
\hline
\end{tabular}

Sumber : Aprilia (2014)

\section{KERANGKA KONSEP PENELITIAN}

Gambar 1

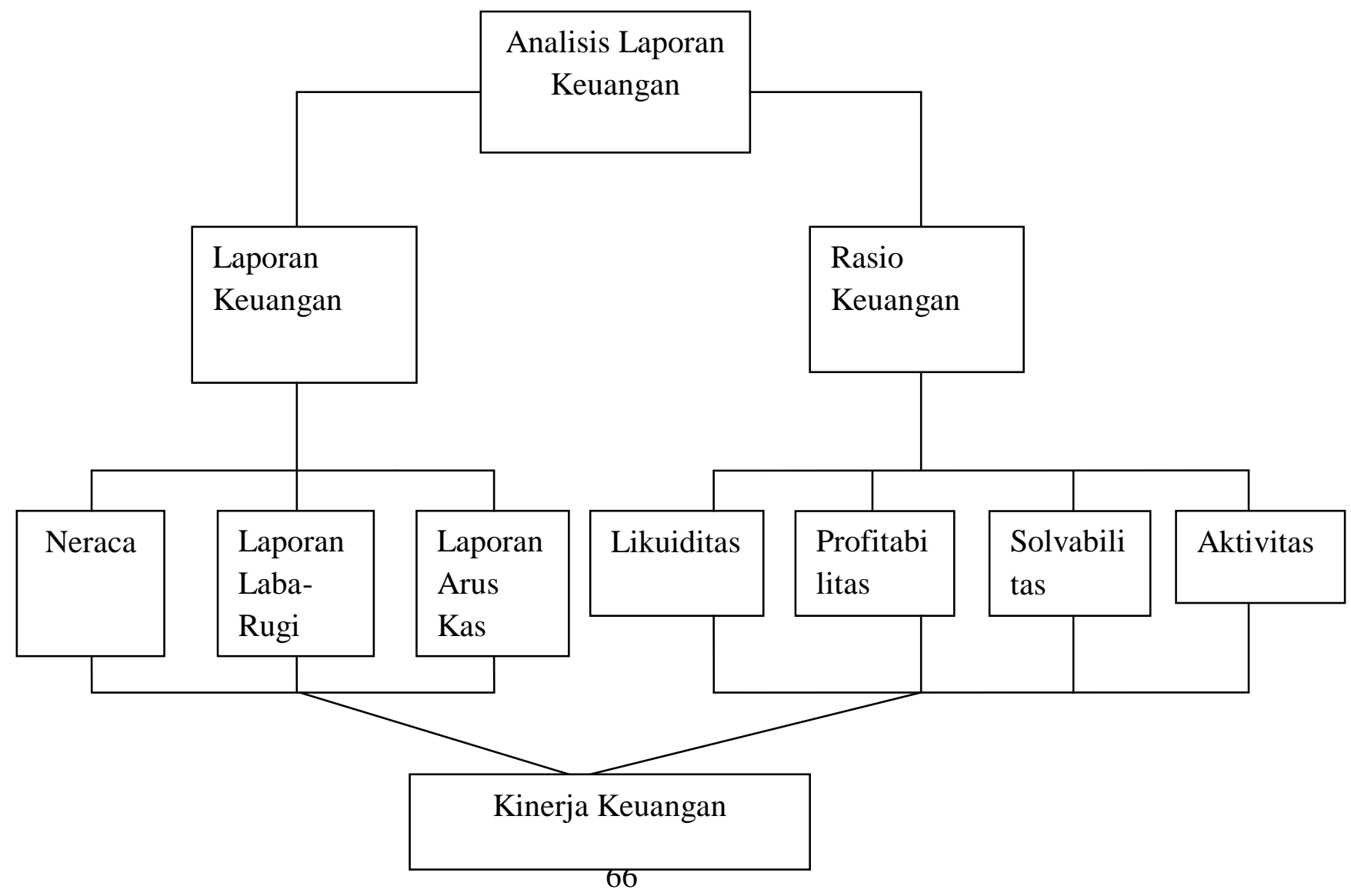




\section{METODE PENELITIAN JENIS DATA}

Menurut Sugiyono (2015:8), metode kuantitatif adalah metode penelitian yang berlandaskan pada filsafat positivism yang digunakan untuk meneliti pada populasi atau sampel, pengumpulan data menggunakan instrument penelitian analisis data yang bersifat kuantitatif / statistic dengan tujuan untuk menguji hipotesis yang telah ditetapkan. Alasan menggunakan motode kuantitatif karena memandang realita / fenomena yang dapat diklasifikasikan, konkrit dan terukur. Penelitian ini pada dasarnya menggunakn populasi dan sampel untuk menjawab rumusan maslah yang digunkan pada teori atau konsep penelitian sehingga dapat disimpulkan dalam hipotesis. Kemudian hipotesis diuji melalui pengumpulan data yang sudah di dapat. Data yang sudah diambil kemudian dianalisis secar kuantitatif dengan menggunakan statistik. Penelitian kuantitatif pada umumnya dilakukan pada sampel yang diambil secara random.

\section{VARIABEL PENGUKURAN}

Pengukuran merupakan variabel indikator variabel dalam penelitian kuantitatif lebih mudah karena pengukuran lebih banyak ditentukan oleh peneliti dengan melihat kecenderungan data dan teknik analisis data yang akan dipakai (Bungin, 2008:94).

Tabel 5

Indikator Pengukuran

\begin{tabular}{|c|c|c|c|}
\hline NO & RASIO & ANALISIS RASIO & RUMUS \\
\hline \multirow[b]{2}{*}{1} & \multirow[b]{2}{*}{ Current Ratio } & \multirow[b]{2}{*}{$\begin{array}{c}\text { RASIO } \\
\text { LIKUIDITAS }\end{array}$} & Aktiva Lancar \\
\hline & & & $\begin{array}{l}\qquad \overline{\text { Kewajiban Lancar }} \\
\text { Sumber : J.F Weston dan Thomas E. } \\
\text { Copeland (1995:254) }\end{array}$ \\
\hline \multirow[b]{2}{*}{3} & \multirow[b]{2}{*}{ Return On Invesment (ROI) } & \multirow{2}{*}{$\begin{array}{c}\text { RASIO } \\
\text { PROFITABILITAS }\end{array}$} & Laba Setelah Pajak \\
\hline & & & $\begin{array}{c}\frac{\text { Total Aktiva }}{\text { Sumber : Sartono (2010:122) }}\end{array}$ \\
\hline \multirow[b]{2}{*}{5} & \multirow[b]{2}{*}{$\begin{array}{l}\text { Total Debt to Total } \\
\text { Capital Assets }\end{array}$} & \multirow[b]{2}{*}{$\begin{array}{c}\text { RASIO } \\
\text { SOLVABILITAS }\end{array}$} & Total Hutang \\
\hline & & & $\begin{array}{c}\frac{\text { Total Aktiva }}{\text { Sumber : J.F Weston dan Thomas E. }} \\
\text { Copeland }(1995: 253-254)\end{array}$ \\
\hline \multirow[b]{2}{*}{7} & \multirow[b]{2}{*}{ Total Assets Turnover } & \multirow{2}{*}{$\begin{array}{c}\text { RASIO } \\
\text { AKTIVITAS }\end{array}$} & Penjualan Netto \\
\hline & & & $\begin{array}{c}\text { Total Aktiva } \\
\text { Sumber: Arifin (2004:11-12) }\end{array}$ \\
\hline
\end{tabular}

Sumber : data diolah 2017

\section{HASIL DAN PEMBAHASAN \\ RASIO LIKUIDITAS \\ Current Ratio}

Berdasarkan tabel 6 dapat diketahui bahwa perusahaan ICBP dan ROTI menghasilkan perbedaan yang jauh, diketahui bahwa rata-rata ICBP mencapai \pm 2.5 dalam tahun 2011-2015 meskipun setiap tahun terkadang mengalami naik turun, sedangkan ROTI dengan rata-rata 1.3 selama 5 tahun. Rasio ini menyatakan bahwa keadaan setiap Rp. 1 aktiva lancar menanggung Rp. 2 hutang lancar yang berarti dalam satu tahun hutang lancar dapat mengembalikan aktiva 
lancar sebanyak 2x. Jadi, jika current ratio tinggi menunjukaan adanya uang kas perusahaan berlebihan dibandingkan dengan tingkat hutang lancarnya atau adanya aktiva lancar yang berlebihan. Sebaliknya, Current Ratio yang rendah lebih riskan tetapi telah menunjukan bahwa manajemen dalam pengoperasian aktiva lancar sudah termasuk efektif.

\section{Tabel 6 \\ Perbandingan Current Ratio ICBP dan ROTI} periode 2011-2015

\begin{tabular}{|c|c|c|c|c|}
\hline $\begin{array}{c}\text { TAHUN/ } \\
\text { KODE } \\
\text { SAHAM }\end{array}$ & $\begin{array}{c}\text { ICBP (dalam } \\
\text { bentuk desimal) }\end{array}$ & Keterangan & $\begin{array}{c}\text { ROTI (dalam } \\
\text { bentuk desimal) }\end{array}$ & Keterangan \\
\hline 2011 & 2.8710712 & (Cukup Baik) & 1.2835307 & (Tidak Baik) \\
\hline 2012 & 2.7625299 & (Cukup Baik) & 1.1246445 & (Tidak Baik) \\
\hline 2013 & 2.4106281 & (Baik Sekali) & 1.1364271 & (Tidak Baik) \\
\hline 2014 & 2.1832023 & (Baik Sekali) & 1.3663997 & (Kurang Baik) \\
\hline 2015 & 2.326008 & (Baik Sekali) & 2.0534215 & (Baik Sekali) \\
\hline
\end{tabular}

Sumber : data diolah 2017

\section{RASIO PROFITABILITAS}

Analisis Return On Invesment (ROI)

\section{Tabel 7}

Perbandingan ROI ICBP dan ROTI periode 2011-2015

\begin{tabular}{|c|r|c|r|c|}
\hline $\begin{array}{c}\text { TAHUN/ } \\
\text { KODE } \\
\text { SAHAM }\end{array}$ & $\begin{array}{c}\text { ICBP (dalam } \\
\text { bentuk desimal) }\end{array}$ & Keterangan & $\begin{array}{c}\text { ROTI (dalam } \\
\text { bentuk desimal) }\end{array}$ & Keterangan \\
\hline 2011 & 0.135741 & (Baik Sekali) & 0.152716 & (Baik Sekali) \\
\hline 2012 & 0.128559 & (Baik Sekali) & 0.123781 & (Baik Sekali) \\
\hline 2013 & 0.105092 & (Baik Sekali) & 0.086693 & (Baik) \\
\hline 2014 & 0.101632 & (Baik Sekali) & 0.088034 & (Baik) \\
\hline 2015 & 0.110056 & (Baik Sekali) & 0.099965 & (Baik) \\
\hline
\end{tabular}

Sumber : data diolah 2017

Dari tabel 7 diatas, perbandingan dari ICBP dan ROTI sangat jauh, ICBP mencapai rata-rata \pm 11 selama 5 tahun, sedangkan rata-rata ROTI mencapai \pm 10 dalam periode 5 tahun. Interpretasi rasio ROI jika semakin besar nilai rasionya, maka semakin besar dana yang dapat dikembalikan dari total asset perusahaan menjadi laba, artinya semakin besar laba bersih yang diperoleh oleh perusahaan maka semakin baik kinerja keuangan perusahaan tersebut.

\section{RASIO SOLVABILITAS}

\section{Analisis Total Debt To Total Capital Assets}

Berdasarkan tabel 8, perbandingan dari ICBP dan ROTI sangat jauh, ICBP rata-rata mencapai \pm 35.5 selama 5 tahun dan mengalami kenaikan untuk setiap tahunnya, sedangkan ROTI rata-rata mencapai \pm 48 selama 5 tahun serta peningkatan yang sangat tajam. Rasio ini membiayai total asset jika semakin tinggi maka perusahaan tersebut tidak sehat karena dimana perusahaan yang memilki rasio hutang yang tinggi dapat mengalami masalah keuangan dan ketika 
nilai rasio yang tinggi menunjukkan tingkat peningkatan dari resiko pada kreditur yang berupa ketidakmampuan perusahaan membayar semua kewajibannya. Suatu perusahaan dikatakan solvabel jika perusahaan tersebut memiliki aktiva dan kekayaan yang cukup untuk membayar hutang-hutangnya. Rasio ini menunjukkan besarnya total hutang terhadap keseluruhan total aktiva yang dimiliki oleh perusahaan.

\section{Tabel 8}

Perbandingan Total Debt To Total Capital Assets ICBP dan ROTI periode 2011-2015

\begin{tabular}{|l|l|l|l|l|}
\hline $\begin{array}{l}\text { TAHUN/ } \\
\text { KODE } \\
\text { SAHAM }\end{array}$ & $\begin{array}{l}\text { ICBP (dalam } \\
\text { bentuk desimal) }\end{array}$ & Keterangan & $\begin{array}{l}\text { ROTI (dalam } \\
\text { bentuk desimal) }\end{array}$ & Keterangan \\
\hline 2011 & 0.296468 & (Baik Sekali) & 0.280181 & (Baik Sekali) \\
\hline 2012 & 0.32482 & (Baik Sekali) & 0.446773 & (Baik) \\
\hline 2013 & 0.376243 & (Baik Sekali) & 0.568035 & (Cukup Baik) \\
\hline 2014 & 0.396234 & (Baik Sekali) & 0.555002 & (Cukup Baik) \\
\hline 2015 & 0.383037 & (Baik Sekali) & 0.56083 & (Cukup Baik) \\
\hline
\end{tabular}

Sumber : data diolah 2017

\section{RASIO AKTIVITAS}

\section{Analisis Total Assets Turn Over}

Tabel 9

Perbandingan Total Assets Turn Over ICBP dan ROTI periode 2011-2015

\begin{tabular}{|c|r|l|r|l|}
\hline $\begin{array}{c}\text { TAHUN/ } \\
\text { KODE } \\
\text { SAHAM }\end{array}$ & $\begin{array}{r}\text { ICBP (dalam } \\
\text { bentuk desimal) }\end{array}$ & Keterangan & $\begin{array}{c}\text { ROTI (dalam } \\
\text { bentuk desimal) }\end{array}$ & Keterangan \\
\hline 2011 & 1.272242 & (Tidak Sehat) & 1.071404 & (Tidak Sehat) \\
\hline 2012 & 1.215243 & (Tidak Sehat) & 0.988283 & (Sangat Tidak Sehat) \\
\hline 2013 & 1.179956 & (Tidak Sehat) & 0.825988 & (Sangat Tidak Sehat) \\
\hline 2014 & 1.199484 & (Tidak Sehat) & 0.877441 & (Sangat Tidak Sehat) \\
\hline 2015 & 1.195043 & (Tidak Sehat) & 0.803489 & (Sangat Tidak Sehat) \\
\hline
\end{tabular}

Sumber : data diolah 2017

Dari tabel 9 diatas, perbandingan dari ICBP dan ROTI sangat jauh, ICBP rata-rata mencapai \pm 1.1 kali selama 5 tahun sedangkan ROTI rata-rata \pm 0.8 serta mengalami penurunan bahkan dikatakan tidak sehat. Rasio ini menggambarkan perputaran aktiva diukur dari volume penjualan. Jadi semakin besar rasio ini semakin baik yang berarti bahwa aktiva dapat lebih cepat berputar dan meraih laba dan menunjukan semakin efisien penggunaan keseluruhan aktiva dalam menghasilkan penjualan, dengan begitu jumlah asset yang sama dapat memperbesar volume penjualan apabila assets turn over diperbesar.

\section{KESIMPULAN}

1. Rasio Likuiditas :

a) Dilihat dari Current Ratio perbandingan 2 perusahaan yang paling bagus adalah ICBP. 
2. Rasio Profitabilitas :

a) Dilihat dari ROI perbandingan 2 perusahaan yang paling bagus adalah ICBP..

3. Rasio Solvabilitas :

a) Dilihat dari Total Debt To Total Capital Assets perbandingan 2 perusahaan yang paling bagus adalah ICBP.

4. Rasio Aktivitas :

a) Dilihat dari Total Assets Turn Over perbandingan 2 perusahaan yang sangat tidak sehat adalah ROTI.

\section{SARAN}

1. Saran untuk Perusahaan

a) Perusahaan harus terus menerus melakukan analisa laporan keuangan untuk menilai dan memutuskan langkah - langkah yang akan di ambil dalam mempertahankan dan meningkatkan kinerja perusahaan.

b) Setiap rasio keuangan perlu dicoba untuk mengetahui kinerja keuangan perusahaan demi mengoptimalkan visi misi perusahaan.

2. Saran untuk Peneliti selanjutnya

a) Peneliti selanjutnya disarankan menggunakan analisis keuangan seperti EVA maupun MVA untuk mengukur kinerja keuangan yang berfokus penciptaan nilai

b) Peneliti selanjutnya disarankan menggunakan Balance Score Card (BSC) untuk mengukur aktivitas-aktivitas operasional perusahaan dalam skala kecil maupun besar. 


\section{DAFTAR PUSTAKA}

Aprilia, Anita. 2014. Analisis Rasio Keuangan Untuk Mengukur Kinerja Keuangan Pada Koperasi Dhaya Harta Jombang. Sekolah Tinggi Ilmu Ekonomi Indonesia (STIESIA) Surabaya

Arifin, Johar. 2004. Analisis Laporan Keuangan Berbasis Komputer. Jakarta : PT Elex Media Komputindo

Bungin, M.Burhan. 2008. Metodologi Penelitian Kuantitatif. Edisi Pertama. Jakarta : Prenada Media Group

Fahmi, Irham. 2011. Analisis Laporan Keuangan. Lampulo: Alfabeta.

Fahmi, Irham. 2012. Pengantar Manajemen Keuangan. Bandung : Alfabeta.

Gandi, Ni luh. G dkk. 2015. Analisis Rasio Likuiditas, Solvabilitas, Profitabilitas dan Metode Economic Value Added (EVA) dalam mengukur Kinerja Keuangan Hotel sunari Villas \& Spa Resort Periode 2009-2013

Laporan Keuangan PT Indofood CBP Sukses Makmur Tbk tahun 2011.

Laporan Keuangan PT Indofood CBP Sukses Makmur Tbk tahun 2012.

Laporan Keuangan PT Indofood CBP Sukses Makmur Tbk tahun 2013.

Laporan Keuangan PT Indofood CBP Sukses Makmur Tbk tahun 2014.

Laporan Keuangan PT Indofood CBP Sukses Makmur Tbk tahun 2015.

Laporan Keuangan PT Nippon Indosari Corpindo Tbk tahun 2011.

Laporan Keuangan PT Nippon Indosari Corpindo Tbk tahun 2012.

Laporan Keuangan PT Nippon Indosari Corpindo Tbk tahun 2013.

Laporan Keuangan PT Nippon Indosari Corpindo Tbk tahun 2014.

Laporan Keuangan PT Nippon Indosari Corpindo Tbk tahun 2015.

Munawir, S. 2012. Analisis Informasi Keuangan. Liberty : Yogyakarta.

Pratama, Heru Andhika Hilarius. 2016. Analisis Kinerja Keuangan Berdasarkan Rasio Likuiditas, Solvabilitas dan Rentabilitas Pada Koperasi CU Dharma Hatiku. Yogyakarta : Universitas Sanata Dharma.

Rahardjo, Budi. 2007. Keuangan \& Akuntansi untuk Manajer Non Keuangan. Yogyakarta : Graha Ilmu.

Sartono, R. Agus. 2010. Manajemen Keuangan Teori dan Aplikasi. Yogyakarta : BPFE. 
Srimindarti, C. 2006. Balanced Scorecard Sebagai Alternatif untuk Mengukur Kinerja. STIE Stikubank. Semarang.

Sugiyono. 2015. Metode Penelitian Kuantitatif, Kualitatif, dan $R \&$ D. Bandung : Alfabeta.

Sutrisno. 2009. Manajemen Keuangan Teori, Konsep dan Aplikasi. Yogyakarta : Ekonisia.

Weston, Fred. J dan Copeland, E. Thomas. 1995. Manajemen Keuangan. Edisi Kesembilan. Jakarta : Binarupa Aksara 